\title{
Model Pengawasan Pembiayaan di BMT Mujahidin Pontianak
}

\author{
Nurma Sari \\ Institut Agama Islam Negeri (IAIN) Pontianak
}

\begin{abstract}
:
This research uses descriptive analysis method which aims to 1) know and describe the system of distribution of the finance products at the BMT Mujahidin in the fiscal year 2009-2011; 2) know and explain the financing implementation at the BMT Mujahidin Pontianak in the fiscal year 2009-2011. Results of the study were: KSU BMT Mujahidin was the same as other Shariah financial institutions, namely the financing run through a series of procedures systematically arranged in part involving the marketing, financing, and managers has been quite effective. The manager accepted the proposals analyzed them and if approved will sign it.

Supervision of the financing was done in three categories, first by doing active field supervision; Second by doing administrative supervision starting from the time of the filing process by way of checking the completeness of requirements until the reimbursement; third by helping the customer to identify the problems that will arise as early as possible in case of trouble and the BMT Mujahidin will participate in finding a solution for the customer.
\end{abstract}

Keywords: BMT, Financing, Supervision

\section{Pendahuluan}

Pasca krisis moneter tahun 1998, hingga kini Indonesia dihadapkan pada kondisi ekonomi yang susah stabil. Bencana alam di berbagai propinsi semakin menambah beban berat pemerintah dalam pembangunan. Sedangkan di pihak masyarakat kecil, keterpurukan juga semakin terus mengancam. 
BMT lahir di tengah-tengah masyarakat dengan tujuan memberikan solusi pendanaan yang mudah dan cepat, terhindar dari jerat rentenir, dan mengacu pada prinsip syariah. Geraknya yang gesit dikelola oleh tenaga-tenaga muda yang progresif dan inovatif, serta pelayanannya yang berorientasi kepada kepuasan pelanggan membuat BMT cepat popular.

Namun realitas keberadaannya ini masih belum selaras dengan tatanan hukum yang ada. Masalah utamanya adalah faktor kelembagaan yang sering menjadi kendala. Sampai saat ini kelembagaan BMT belum diatur secara spesifik sebagaimana lembaga-lembaga keuang mikro lainnya. Kebanyakan BMT saat ini menyatakan dirinya sebagai koperasi, artinya secara badan hokum BMT tunduk pada undang-undang perkoperasian. BMT yang menyatakan dirinya sebagai koperasi yang bergerak di bidang simpan-pinjam harus mampu memenuhi persyaratan-persyaratan legalitas sebagai koperasi, seperti Anggaran Dasar, keanggotaan, permodalan, tata organisasi dan cara kerja lainnya. Sebagian praktisi BMT menganggap adopsi kelembagaan koperasi terhadap BMT ini seperti mengingkari kenyataan sejarah, selain bertentangan dengan jatidiri gerak BMT di tanah air.

Realitas lainnya berkenaan dengan pengawasan. Beroperasinya BMT memang dibutuhkan oleh masyarakat, dengan kata lain, memberikan manfaat bagi masyarakat. Hanya saja pengawasan terhadap operasional BMT belum terumuskan dengan jelas karena kebelumjelasan perangkat untuk itu. Para pelaku BMT pun juga telah menyadari kondisi ini. Walaupuntelah dibentuk berbagai asosiasi BMT yang berperan dalam merumuskan standarisasi, advokasi dan pengawasan, namunsampai saat ini belum mendapatkan legalitas yang memadai secara hokum nasional.

Kenyataan lainnya, gairah munculnya begitu banyak BMT ini tidak dibarengi dengan faktor-aktor pendukung yang memungkinkan BMT untuk terus berkembang dan berjalan dengan baik. Fakta yang ada di lapangan menunjukkan banyak BMT yang tenggelam dan bubar disebabkan oleh berbagai macam sebab seperti; manajemennya yang amburadul, pengelola yang tidak amanah, sumber daya manusia yang kurang mampu bekerja professional, tidak dapat menarik kepercaya- 
an masyarakat, kesulitan modal dan seterusnya. Akibatnya, citra yang timbul di masyarakat adalah BMT identik dengan lembaga yang sangat buruk, tidak dapat dipercaya, hanya menjual isyu syariah, bisnisnya orang yang ingin punya bank tapi tidak mau ikut aturan perbankan dan sebagainya.

KSU BMT Mujahidin dalam ruang lingkup lembaga keuangan Mikro yang ada di Pontianak, telah mampu bertahan dan bersaing dengan lembaga keuangan mikro lain dari tahun pendiriannya yaitu tahun 1996 sampai dengan sekarang tahun 2012, jadi kira-kira sudah 16 tahun. Itu semua terlihat dari hasil yang telah dicapai dari tahun ke tahun menunjukkan hasil yang cukup baik dari sisi jumlah simpanan, pembiayaan, modal dan asset, maupun jumlah anggota mitra. KSU BMT Mujahidin sampai tahun 2011 sudah mendapatkan penghargaan dari Kantor Koperasi sebagai Koperasi Berprestasi dengan Nilai Sehat dan Sangat Baik, dan penghargaan dari Bank Syariah Mandiri, tingkat nasional.

KSU BMT Mujahidin dikatakan mampu memberikan pembiayaan kepada masyarakat, ini terlihat dari besarnya jumlah piutang yang dimiliki KSU BMT Mujahidin. Pada tahun 2011 BMT Mujahidin memiliki piutang pembiayaan Rp.3.900.531.889,53 tahun 2010 piutang pembiayaan Rp. 3.767.095.163,37 tahun 2009 piutang pembiayaan Rp.2.769.870.281,28.

Kemampuan menghasilkan laba bukan menjadi tujuan utama tetapi ini penting guna mensejahterakan stakeholder dan pihak-pihak terkait tanpa mengesampingkan prinsip-prinsip syariah yang dijalankan.

Hal itu menuntut ketepatan sasaran pemasaran produk yang dikemas agar mampu memenuhi keinginan nasabah karena aktiva yang dimiliki akan bernilai kecil tanpa adanya pelanggan, itu disebabkan tidak adanya transaksi pembiayaan, dana akan mengendap dan dalam dunia perbankan ini tidak berarti baik oleh karena itu tugas utamanya adalah menarik dan mempertahankan langganan agar mencapai target yang telah ditetapkan. Yang menjadi fokus dalam penelitian ini adalah implementasi produk pembiayaan pada BMT Mujahidin tahun buku 2009-2011. Adapun sub fokusnya adalah sebagai berikut: 1) Bagaimana sistem penyaluran produk pembiayaan pada BMT Mujahidin Pontianak tahun buku 2009-2011; 2). Bagaimana pengawasan terhadap pembiayaan 
yang telah disalurkan oleh BMT Mujahidin Pontianak tahun buku 20092011.

\section{Pengertian BMT (Baitul Mal wat-Tamwil)}

Pengertian BMT secara definitive adalah balai usaha mandiri terpadu yang isinya berintikan konsep baitul maal wat tamwil. (Ahmad Rodoni, Abdul Hamid, 2008: 60). Kegiatan BMT adalah mengembangkan usahausaha produktif dan investasi dalam meningkatkan kualitas kegiatan ekonomi pengusaha mikro dan kecil, antara lain mendorong kegiatan menabung dan pembiayaan kegiatan ekonominya. Sedangkan kegiatan baitul mal menerima titipan BAZIS dari dana zakat, infaq dan shadaqah dan menjalankannya sesuai dengan peraturan dan amanahnya. Dalam definisi operasional PINBUK BMT adalah lembaga usaha ekonomi rakyat kecil yang beranggotakan orang atau badan hokum berdasarkan prinsip syariah dan prinsip koperasi. BMT diharapkan menjadi lembaga pendukung kegiatan ekonomi masyarakat kecil bawah dengan berlandaskan prinsip syariah.

Dengan mengacu pada pengertian tersebut, BMT merupakan lembaga perekonomian rakyat kecil yang bertujuan meningkatkan dan menumbuh kembangkan kegiatan ekonomi pengusaha mikro dan kecil yang berkualitas dengan mendorong kegiatan menabung dan menunjang kegiatan perekonomiannya.

Dalam melaksanakan kegiatannya, BMT mempunyai asas dan landasan, visi, misi, fungsi dan prinsip-prinsip serta ciri khas yang dimiliki oleh BMT sebagai sebuah lembaga keuangan syariah non bank yang mempunyai legalitas dan berbadan hokum. BMT didirikan secara berproses dan bertahap yang dimulai dari Kelompok Swadaya Masyarakat (KSM), dan bila telah memenuhi syarat anggota dan pengurus dapat ditingkatkan menjadi lembaga berbadan hokum koperasi. Selanjutnya bila telah memenuhi syarat asset dengan jumlah tertentu, BMT harus mempersiapkan proses administrasi untuk menjadi sebuah badan usaha yang sehat, yang dikelola secara syariah, mengedepankan etika dan perilaku yang Islami. 
Koperasi sebagai bentuk badan hokum BMT mempunyai pengertian sebagaimana dituangkan dalam undang-undang No. 25 Tahun 1992. Menurut etimologi, koperasi berasal dari kata "cooperation", terdiri dari dua suku kata yang artinya berusaha bersama. Sedangkan menurut Undang-Undang No. 25/1992, koperasi adalah badan usaha yang beranggotakan orang-orang atau badan-badan dengan berlandaskan kegiatan berdasarkan atas asas kekeluargaan. Pengertian tersebut sesuai dengan bunyi pasal 33 ayat (1) Undang-Undang Dasar 1945.

Sebagai suatu badan usaha, koperasi harus mempunyai kegiatan usaha yang jelas baik di bidang produksi, konsumsi, simpan pinjam dan jasa lainnya. Koperasi beranggotakan orang-orang atau badan hokum dimaksudkan bahwa koperasi mempunyai minimal 20 orang anggota yang memenuhi syarat dan susunan kepengurusan sebagaimana di atur dalam AD dan ART koperasi (Anggaran Dasar dan Anggaran Rumah Tangga). Koperasi berasaskan kekeluargaan, artinya dalam melaksanakan kegiatan usahanya badan usaha koperasi senantiasa menjunjung tinggi asas kekeluargaan dan kebersamaan (dari anggota, oleh anggota, untuk anggota) dalam semua kegiatan usahanya. Rapat Anggota merupakan keputusan tertinggi, pengurus mempertanggungjawabkan semua hasil kerja yang telah diamanatkan kepadanya dalam rapat anggota tahunan (RAT) yang merupakan ajang pertemuan semua anggota dan pengurus untuk membuat rumusan berdasarkan laporan dan data yang telah dipertanggung-jawabkan, mengevaluasi, dan bagaimana meningkatkan program dan target serta kebijaksanaannya apada masa yanga kan dating dalam rangka meningkatkan pelayanan dan kesejahteraan para anggota.

Dengan demikian Baitul Maal wat Tamwil (BMT) adalah sebuah lembaga ekonomi kerakyatan yang berusaha membangun kegiatan usaha produktif dan infestasi dalam rangka menumbuhkembangkan dan meningkatkan kegiatan ekonomi pengusaha kecil berdasarkan prinsip syariah dan koperasi. Selain itu BMT juga merupakan sarana pengelolaan dana ummat, dari ummat oleh umat dan kembali untuk ummat (demokratisasi ekonomi) berdasarkan prinsip-prinsip ekonomi Islam.

Sebagai salah satu lembaga perekonomian ummat, baitul maal wat tamwil memiliki beberapa tujuan antara lain: 
a. Meningkatkan dan mengembangkan potensi ummat dalam program pengentasan kemiskinan, khususnya pengusaha kecil/lemah.

b. Memberikan sumbangan aktif terhadap upaya pemberdayaan dan peningkatan kesejahteraan ummat.

c. Menciptakan sumber pembiayaan dan penyediaan modal bagi anggota dengan prinsip syariah.

d. Mendorong sikap hemat dan gemar menabung.

e. Menumbuhkan usaha-usaha yang produktif.

f. Membantu para pengusaha lemah untuk mendapatkan modal pinjaman dan membebaskan dari sistem riba.

g. Menjadi lembaga keuangan alternative yang dapat menopang percepatan pertumbuhan ekonomi nasional.

h. Meningkatkan kualitas dan kuantitas kegiatan usaha, di samping meningkatkan kesempatan kerja dan penghasilan ummat.

Pembiayaan modal kerja yaitu: pembiayaan yang digunakan untuk memenuhi kebutuhan peningkatan produksi, baik secara kuantitatif yaitu hasil jumlah produksi, maupun kualitatif yaitu peningkatan kualitas atau mutu hasil produksi dan untuk keperluan perdagangan atau peningkatan utility of place dari suatu barang. Berdasarkan beberapa definisi diatas dapat diwujudkan dalam beberapa produk pembiayaan, sebagai berikut:

\section{Produk-produk Pembiayaan di BMT dan Karakteristiknya}

Baitul Maal wat-Tamwil (selanjutnya disebut BMT) adalah lembaga keuangan mikro yang sasaran utamanya pun pengusaha mikro berfungsi sebagai financial intermediary ini terlihat dari berbagai model pembiayaan dan karakteristiknya yang terdapat di BMT diantaranya (Sudarsono, 2004: 165).

\section{a. Murabahah}

Murabahah adalah akad jual beli suatu barang dimana penjual menyebutkan harga jual yang terdiri atas harga pokok barang dan tingkat keuntungan tertentu dimana harga jual tersebut disetujui oleh pembeli. 
Landasan syar'i dari mudharabah lebih mencerminkan anjuran untuk melakukan usaha. Hal ini tampak dalam beberapa ayat dan alHadist berikut:

“...dan dari orang-orang yang berjalan di muka bumi mencari sebagian karunia Allah Swt (QS. al-Muzammil: 20).

Ayat di atas menjadi wajhud dilalah atau argumen dari surat al-Muzammil: 20 adanya kata yadhribun yang sama akar kata mudharabah yang berarti melakukan usaha perjalanan usaha.

Teknisnya lembaga melakukan pembelian kepada supplier yang ditunjuk nasabah atau lembaga. Kemudian lembaga menetapkan harga jual berdasarkan kesepakatan bersama nasabah, nasabah dapat melunasi pembelian dengan cara langsung atau angsuran.

Adapun ketentuan yang terdapat dalam murabahah adalah, ada rukun dan syarat. Adapun rukun-rukun murabahah adalah:

1). Pihak yang berakad; yaitu: a) Penjual; dan b) Pembeli

2). Objek yang diakadkan; yaitu: a) Harga; b) Barang yang diperjual belikan

3). Akad/Sighat; yaitu: a) Serah (ijab); b) Terima (kabul)

Adapun syarat murabahah adalah:

1). Pihak yang berakad; yaitu: a) Cakap hukum; b) Sukarela, tidak dalam keadaan terpaksa.

2). Objek yang diperjual belikan; Objek harus memenuhi kriteria:

a) Tidak termasuk yang diharamkan;

b) Bermanfaat;

c) Penyerahannya dari penjual ke pembeli dapat dilakukan;

d) Merupakan hak milik penuh pihak yang berakad;

e) Sesuai spesifikasinya antara yang diserahkan penjual dan yang diterima pembeli.

3). Akad/Sighat; Akad harus memenuhi syarat:

a) Harus jelas dan disebutkan secara spesifik dengan siapa berakad;

b) Antara ijab dan qabul harus selaras baik dalam spesifikasi barang 
maupun harga yang disepakati;

c) Tidak mengandung klausal yang bersifat menggantung keabsahan transaksi padahal kejadian akan datang;

d) Tidak membatasi waktu. (Tim Pengembangan Perbankan Syariah, 2003: 76-77).

\section{b. Mudharabah}

Mudharabah adalah menyerahkan modal berupa uang kepada orang yang berniaga sehingga mendapatkan persentase keuntungan. Adapun mudharabah meliputi rukun dan syarat.

Rukun-rukun mudharabah adalah:

1). Ada dua pihak atau lebih, mereka adalah investor dan pengelola modal

2). Ada objek transaksi, yakni: modal, usaha dan keuntungan.

3). Pelafalan perjanjian, (Al Jazairi dalam Veitzal, 2012: 300-301)

Sedangkan syarat-syarat mudharabah adalah yang berhubungan dengan rukun mudharabah itu sendiri yaitu:

a). Orang yang berakad; mereka baik sahibul mal atau mudharib harus memenuhi syarat cakap bertindak hukum. Sedangkan mudharib itu sendiri punya kebebasan untuk melakukan usaha (Veitzal, 2012: 300- 301).

b). Objek Akad

Modal harus memenuhi syarat-syarat sebagai berikut:

1) Modal harus berbentuk tunai seperti emas perak batangan dan bukan barang komoditi atau harta benda baik bergerak atau barang tetap karena harganya berubah-ubah yang akan membawa perselisihan antara kedua belah pihak (Az-Zuhaili, 1989: 843);

2) Selain itu modal harus kontan dan tidak boleh berbentu hutang;

3) Modal juga harus diserahkan atau dibayar kepada pengelola supaya dia dapat mengurusnya sendiri; 
4) Serta modal harus diketahui jumlah dan jenisnya pada saat perjanjian dibuat suapaya tidak menimbulkan perselisihan kedua belah pihak.

c). Pekerjaan; Pekerjaan adalah hak eksklusif pengelola tanpa campur tangan pemilik modal, pemilik modal tidak boleh membatasi tindakan pengelola sedemikian rupa untuk mencegahnya dari mencapai tujuan mudharabah yaitu keuntungan (Al-Jazairi, 1996: 44). Pengelola tidak boleh menyalahi hukum syariat Islam dalam tindakannya yang berhubungan dengan mudharabah dan harus mematuhi kebiasaan yang berlaku dari aktivitas itu. Pengelola harus mematuhi syarat-syarat yang ditentukan oleh pemilik modal jika syarat-syarat tersebut tidak kontadiktif dengan apa yang ada dalam kontrak mudharabah.

\section{c. Musyarakah}

Musyarakah adalah akad kerja sama antara dua pihak atau lebih untuk suatu tertentu di mana masing-masing pihak memberikan kontribusi dana sesuai dengan kesepakatan bahwa keuntungan dan resiko akan ditanggung bersama sesuai dengan kesepakatan. Adapun jenis-jenis al musyarakah yakni syirkhah al-'inan, adalah kontrak antara dua orang atau lebih setiap pihak memberikan suatu porsi dari keseluruhan dana dan berpartisipasi dalam kerja. Kedua belah pihak terbagi dalam keuntungan dan kerugian sebagaimana yang telah disepakati di antara mereka. Akan tetapi, porsi masing-masing pihak, baik dalam dan maupun kerja dalam bagi hasil, tidak harus sama atau identik sesuai dengan kesepakatan mereka.

Syirkhah al-muwafadhah, adalah kontrak kerja sama antara dua orang atau lebih setiap pihak memberikan suatu porsi dari keseluruhan dana dan berpartisipasi dalam kerja. Setiap pihak membagi keuntungan dan kerugian secara sama. Dengan demikian syarat utama dari jenis pola ini adalah kesamaan dana yang dijadikan modal diikuti dengan tanggung jawab masing-masing pihak.

Syirkhah al-a'maal, adalah kontrak kerjasama dua orang seprofesi untuk menerima pekerjaan secara bersama dan berbagi keuntungan dari 
pekerjaan itu. Misalnya kerjasama dua orang arsitek untuk menggarap proyek atau kerjasama dua orang penjahit untuk menerima order pembuatan seragam sebuah kantor.

Syirkhah al-wujuh, adalah kontrak di antara dua orang atau lebih yang memiliki reputasi dan prestasi baik serta ahli dalam bisnis. Mereka membeli barang secara kredit dari suatu lembaga perusahaan dan menjual barang tersebut secara tunai, mereka berbagi dalam keuntungan dan kerugian berdasarkan jaminan kepada penyuplai yang disiapkan oleh tiap mitra. Jenis al-musyarakah ini tidak memerlukan modal karena pembelian secara kredit berdasarkan pada jaminan tersebut, karena kontrak ini lazim disebut sebagai musyarakah piutang. Menurut Sudarsono (2003: 111) musyarakah dibagi dua, musyarakah amlak dan musyarakah uqud.

Syirkah amlak berarti eksistensi suatu perkongsian tidak perlu kepada suatu kontrak membentuknya tetapi terjadi dengan sendirinya. Bentuk syirkah amlak ini terbagi syirkah amlak jabr dan syirkah amlak ikhtiar.

Syirkah amlak Jabr, adalah bentuk perkongsian yang terjadi bersifat otomatis dan paksa. Paksa tidak ada alternatif untuk menolaknya. Hal ini terjadi dalam proses waris mewaris, manakala dua saudara atau lebih menerima warisan dari orang tua mereka.

Syirkah amlak Ikhtiar, adalah bentuk perkongsian secara otomatis tetapi bebas. Otomatis berarti tidak memerlukan kontrak. Bebas adanya pilihan atau option untuk menolak, contoh dari jenis perkongsian ini dapat dilihat apabila dua orang atau lebih mendapatkan hadiah atau wasiat bersama dari pihak ketiga.

Dari kedua bentuk kontrak di atas mempunyai karakteristik yang berbeda dari syarikat-syarikat lainnya mereka dalam kedua syarikat ini masing-masing anggota tidak mempunyai (hak untuk mewakilkan dan mewakili) terhadap partnernya.

Syirkah uqud, adalah perkongsian yang terbentuk karena suatu kontrak, ada beberapa macam syirkah uqud:

Inan, adalah syirkah yang memiliki karakteristik sebagai berikut. Pertama, besarnya penyertaan modal dari masing-masing anggota tidak harus sama. Kedua, masing-masing anggota mempunyai hak penuh untuk aktif langsung dalam pengelolaan usaha, tetapi ia juga dapat meng- 
gugurkan hak tersebut dari dirinya. Ketiga, pembagian keuntungan dapat didasarkan atas prosentase modal masing-masing, tetapi dapat pula atas dasar negosiasi. Hal ini diperkenankan karena adanya kemungkinan tambahan kerja atau penanggung resiko dari salah satu pihak. Keempat, kerugian keuntungan bersama sesuai besar penyertaan modal masingmasing.

Muwafaqah, dalam konteks ini muwafaqah menegaskan pertama, penyertaan modal dari setiap anggota. Kedua, setiap anggota menjadi wakil dan kafil (guarantor) bagi partner lainnya, untuk itu keaktifan semua anggota dalam pengelolaan usaha menjadi keharusan. Ketiga, pembagian keuntungan dan kerugian didasarkan atas besarnya modal masingmasing.

Wujuh, dalam konteks syirkah wujuh ini para anggota hanya menghandalkan wujuh (wibawa dan nama baik) mereka dan unsur modal atau dana sama sekali absen darinya, pembagian untung rugi dilakukan secara negosiasi di antara para anggota.

Abdan, adalah syirkah di mana dua orang atau lebih yang sama atau kedekatan bentuk kerjanya menerima pesanan dari pihak ketiga dan membagi keuntungan melalui negosiasi bersama.

Adapun manfaat dari bentuk al musyarakah ini: pertama, Bank atau BMT akan menikmati peningkatan dalam jumlah tertentu pada saat keuntungan usaha konsumen meningkat. Kedua, Bank atau BMT tidak berkewajiban membayar dalam jumlah tertentu kepada konsumen perdana secara tetap tetapi disesuaikan dengan pendapatan atau hasil usaha Bank atau BMT, sehingga Bank atau BMT tidak akan pernah mengalami negatif spread. Ketiga, pengambilan pokok pembiayaan disesuaikan dengan cash flow atau arus kas usaha konsumen sehingga tidak memberatkan konsumen. Keempat, Bank atau BMT akan lebih selektif dan hati-hati (prudent) mencari usaha yang benar-benar halal, aman, dan menguntungkan. Hal ini karena keuntungan yang riil dan benar-benar terjadi itulah yang akan dibagikan. Kelima, Prinsip bagi hasil dalam mudharabah atau musyarakah ini berbeda dengan prinsip bunga tetap di mana Bank atau BMT akan menagih penerima pembiayaan (konsumen), satu jumlah bunga tetap pun keuntungan yang dihasilkan konsumen, 
bahkan sekali pun merugi dan terjadi krisis ekonomi.

Bentuk yang kedua adalaha Mudharabah, mudharabah adalah akad kerjasama usaha antara dua pihak di mana pihak pertama menyediakan $100 \%$ modal, sedangkan pihak lain menjadi pengelola. Keuntungan usaha secara mudharabah dibagi menurut kesepakatan yang dituangkan kontrak. Sedangkan apabila rugi ditanggung pemilik modal selama kerugian bukan akibat kelalaian pengelola, seandainya kerugian akibat kecurangan atau kelalaian pengelola, maka pengelola bertanggung jawab atas kerugian tersebut. Mudharabah terdiri dari mudharabah mutlaqah, muqayyadah.

Adapun makna lanjut konsep mudharabah mutlaqah adalah bentuk kerjasama di antara pemilik modal (shahibul maal) dan pengelola (mudharib) yang cakupannya sangat luas dan tidak dibatasi oleh spesifik oleh jenis usaha, waktu, dan lokasi usaha. Dalam kajian fiqh, ulama memberikan contoh dengan ungkapan if'al ma syi'fa (lakukan sesukamu) dari pemilik modal (shahibul maal) ke pengelola (mudharib) yang member kekuasaan sangat besar.

Adapun makna dari konsep mudharabah muqayyadah adalah sebuah bentuk kerjasama akan tetapi pemilik modal (mudharib) dibatasi dengan batasan jenis usaha, waktu, atau tempat usaha. Adanya pembatasan ini seringkali mencerminkan kecenderungan umum pemilik modal (shahibul maal) dalam memasuki jenis dunia usaha.

\section{d. Bai'u Bithaman Ajil}

Bai'u bitsaman ajil adalah pembiayaan berakad jual beli dimana lembaga menyediakan dananya untuk sebuah investasi atau pembelian barang modal dan usaha yang kemudian proses pembayarannya dilakukan secara mencicil atau angsuran. Jumlah kewajiban yang harus dibayarkan oleh peminjam adalah jumlah atas harga barang modal dan mark-up yang disepakati. Prinsip yang digunakan adalah sama seperti murabahah (Muhamad, 2000: 119).

\section{e. Al-Qardhul Hasan}

Qardhul hasan adalah perjanjian pinjaman untuk tujuan social kepada mereka yang tergolong lemah ekonominya (Remi, 2005: 75). 
Qardul hasan diberikan kepada:

i. Mereka yang memerlukan pinjaman konsumtif jangka pendek untuk tujuan yang sanngat urgen

ii. Para pengusaha kecil yang kekurangan dana tetapi mempunyai prospek bisnis yang sangat baik.

Transaksi Qardh dianggap sah apabila memenuhi rukun dan syarat yang telah ditentukan. Dan Rukun Qardh adalah: 1) Peminjam (muqtarid); 2) Pemberi pinjaman (muqtarid);3) Dana (qardi); dan 4) Serah terima (ijab qabul)

Sedangkan syarat Qardh yang harus dipenuhi adalah: 1) Dana yang digunakan ada manfaatnya; dan 2) Ada kesepakatan diantara kedua belah pihak

\section{Sistem dan Prosedur Bagi Hasil}

\section{Sistem Bagi Hasil dalam Pembiayaan}

Pada mekanisme perbankan bagi hasil adalah konsep yang paling lazim dan hampir seluruh ulama sepakat dengan transaksi bagi hasil (Tim Pengembangan Perbankan Syariah, 2003: 69). Transaksi bagi hasil yang dapat diterapkan dalam perbankan Islam pada umumnya dibagi dalam dua jenis transaksi yaitu mudharabah dan musyarakah. Tetapi pada perkembangannya untuk produk murabahah, BBA, bagi hasil antara nasabah dan perbankan berupa mark-up (selisih harga jual dan harga beli).

Sebelum sampai pada tahap bagi hasil yang harus dilakukan lebih dahulu adalah menentukan nisbah. Nisbah adalah rasio atau perbandingan pembagian keuntungan (bagi hasil) antara sahibul maal dan mudharib.

Nisbah merupakan porsi pembagian biasanya berhubungan dengan bagi hasil usaha, misalnya nisbah antara pemilik uang dengan pengelola berbanding 60: 40. Nisbah bagi hasil diterapkan pada produkproduk pembiayaan yang berbasis natural uncertainty contracts yakni akad bisnis yang tidak memberikan kepastian pendapatan baik dari segi jumlah, maupun waktu (Karim, 2004: 260). Yang termasuk akad ini adalah kontrak-kontrak investasi dimana yang bertransaksi saling 
mencampurkan asetnya menjadi satu dan menanggung risiko bersamasama untuk mendapat keuntungan, artinya keuntungan dan kerugian ditanggung bersama.

Terdapat tiga metode dalam menentukan nisbah/bagi hasil pembiayaan yakni:

a. Penentuan nisbah bagi hasil keuntungan usaha yang dibiayai dihitung dengan mempertimbangkan:

1) Perkiraan penjualan;

2) Lamanya perputaran kas;

3) Perkiraan biaya langsung dan tidak langsung;

4) Delayed factor.

b. Penentuan nisbah bagi hasil pendapatan usaha yang dibiayai dihitung dengan mempertimbangkan:

1) Perkiraan penjualan;

2) Lamanya perputaran kas;

3) Perkiraan biaya langsung;

4) Delayed factor.

c. Penentuan nisbah bagi hasil penjualan dengan mempertimbangkan:

1) Perkiraan penjualan;

2) Lamanya perputaran kas;

3) Delayed factor.

\section{Prosedur Pembiayaan}

Pembiayaan merupakan salah satu fungsi perbankan sebagai financial intermediary dan memiliki tujuan memperoleh keuntungan bagi kesejahteraan stakeholder oleh karena itu kualitas pembiayaan sangat berpengaruh terhadap efektivitas pendapatan yang diharapkan. Menurut Arifin (2004: 219) untuk mewujudkan hal itu diperlukan satuan kerja pembiayaan yang sehat meliputi: prosedur pembiayaan, prosedur administrasi, serta prosedur pengawasan pembiayaan. Adapun proses yang harus diaplikasikan adalah: 


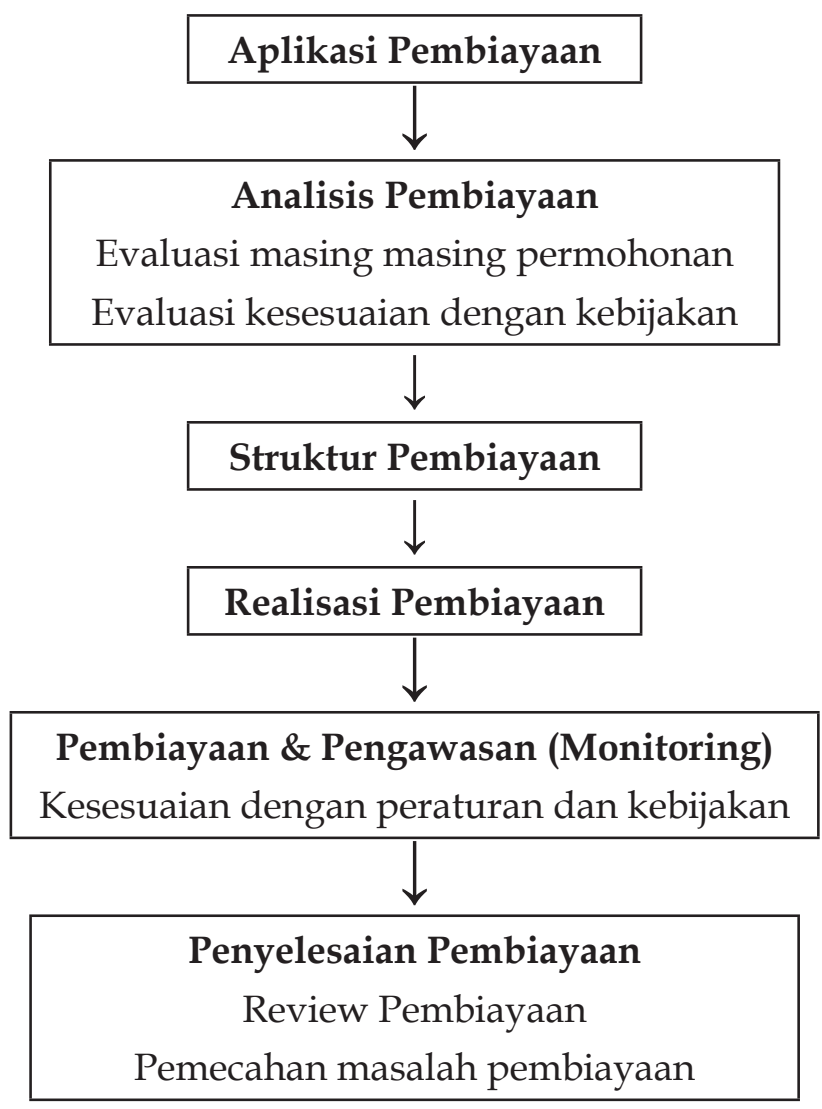

\section{a. Analisis Pembiayaan}

Mengingat sumber dana yang dimiliki sebagian adalah berasal dari pihak yang surplus dana, maka dalam sebuah pembiayaan diperlukan analisis kredit untuk mencegah terjadinya default oleh calon debitur. Default adalah kegagalan nasabah dalam memenuhi kewajibannya untuk melunasi kredit yang diterima berdasarkan akad yang dibuat. Untuk itu diperlukan analisis berdasarkan prinsip "6C dan 6A". (Lukman Dendawijaya, 2003: 91-100):

Adapun analisis berdasarkan prinsip " 6 C" yang meliputi:

- Character, analisis mengenai watak berkaitan dengan integritas dari calon debitor. Integritas ini sangat menentukan willingness to pay atau kemampuan membayar kembali.

- Capital,perbandingan antara besarnya pembiayaan dari lembaga 
dengan besarnya model sendiri yang dapat disediakan nasabah (debt to equity ratio).

- Capacity, penilaian terhadap calon nasabah kredit dalam hal kemampuan memenuhi kewajiban yang telah disepakati dalam perjanjian pinjaman.

- Conditions of economy, faktor bisnis yang berada di lingkungan sekitar lokasi usaha.

- Collateral, barang-barang yang diserahkan peminjam kepada lembaga sebagai jaminan atas kredit pinjaman yang diterimanya.

- Constraints, faktor hambatan berupa social psikologi yang ada pada suatu daerah atau wilayah tertentu yang menyebabkan suatu proyek tidak dapat dilaksanakan.

Setelah melakukan pendekatan analisis kemudian dilanjutkan dengan analisis pembiayaan berdasarkan prinsip " $6 \mathrm{~A}$ " sebagai berikut:

- Analisis aspek yuridis, bertujuan untuk meneliti ketentuan-ketentuan legalitas dari usaha yang akan memperoleh bantuan pembiayaan.

- $\quad$ Analisis aspek pasar dan pemasaran, bertujuan untuk meneliti kemungkinan pangsa pasar yang diraih.

- Analisis aspek teknis, bertujuan untuk menilai seberapa jauh kemampuan pengelola usaha dalam mempersiapkan dan melaksanakan usaha tersebut.

- Analisis aspek manajemen, bertujuan untuk menilai kemampuan dan kecakapan dari manajemen menjalankan bisnisnya.

- Analisis aspek keuangan, bertujuan untuk menilai kemampuan dan kecakapan dari manajemen usaha dalam bidang keuangan.

- Analisis aspek social ekonomi, bertujuan untuk menilai sejauh mana usaha yang akan dibangun dan dibiayai memiliki value added yang tinggi dilihat dari sudut pandang social maupun makro ekonomis.

Setelah menganalisis usaha yang dimiliki oleh nasabah pembiayaan 
jika layak untuk dibiayai maka, dilanjutkan dengan administrasi pembiayaan, hal-hal yang perlu diperhatikan dalam administrasi pembiayaan yaitu: (Muhammad, 2005: 57)

1) Penerimaan keputusan

2) Penerusan kepada nasabah jika disetujui, maka dilanjutkan memuat berbagai persyaratan klausula.

3) Penandatanganan akad di hadapan petugas pembiayaan

\section{b. Pemantauan dan Pengawasan}

Pembiayaan merupakan kegiatan utama bank sebagai usaha untuk memperoleh laba, tetapi rawan resiko yang tidak saja dapat merugikan lembaga keuangan tapi juga berakibat kepada masyarakat kepada masyarakat penyimpan dan pengguna dana oleh karena itu bank harus menerapkan fungsi: pengawasan yang menyeluruh (Multi Layers Control) dengan tiga prinsip pencegahan secara dini (early warning system), prinsip pengawasan melekat (Build in Control) dan prinsip pemeriksaan internal (Internal Audit). (Arifin, 2001: 221-222).

Pencegahan dini adalah tindakan prefentif terhadap kemungkinan terjadinya hal-hal yang dapat merugikan bank alam pembiayaan atau terjadinya praktek-praktek pembiayaan yang tidak sehat. Pencegahan secara dini dilakukan dengan cara menciptakan struktur pengendalian internal. Struktur pengendalian internal ini harus diterapkan pada semua tahap proses pembiayaan, mulai dari permohonan.

Selanjutnya diperlukan pengawasan melekat dimanapun pejabat pembiayaan melakukan supervise sehari-hari untuk memastikan bahwa kegiatan pembiayaan telah berjalan sesuai dengan kebijakan yang telah ditetapkan, hasil kegiatan supervise ini minimal berupa laporan-laporan tetang:

1) Hasil penelitian kualitas portofolio pembiayaan secara menyeluruh disertai dengan penjelasannya.

2) Ada atau tidaknya pembiayaan yang dilakukan menyimpang dari kebijakan pokok pembiayaan ketentuan syari'ah.

3) Besarnya tunggakan pembayaran kembali pembiayaan yang telah 
diberikan dan pembayaran bagi hasilnya.

4) Pelanggaran/penyimpangan yang dilakukan oleh pejabat yang berada dibawah supervisinya.

Pengawasan pembiayaan juga harus dilengkapi dengan audit internal terhadap semua aspek pembiayaan yang telah dilakukan untuk memastikan bahwa pembiayaan dilakukan dengan benar sesuai dengan kebijakan pembiayaan yang sehat serta memenuhi ketentuan-ketentuan yang berlaku dalam pembiayaan.

\section{c. Penanganan Pembiayaan Bermasalah}

Penyebab terjadinya pembiayaan bermasalah adalah karena kesulitan keuangan yang dihadapi nasabah. Penyebab kesulitan keuangan nasabah dapat dibagi menjadi dua, yaitu yang bersumber dari faktor internal dan faktor eksternal (Arifin, 2004: 223-224).

1) Faktor internal

Adalah faktor yang berada di dalam usaha itu sendiri dapat dilihat dari beberapa hal seperti kelemahan pembelian dan penjualan.

2) Faktor eksternal

Adalah faktor yang berada di luar usaha seperti: bencana alam peperangan, perubahan kondisi perekonomian.

Bila kemacetan disebabkan faktor eksternal bank tidak perlu lagi melakukan analisis lebih lanjut yang perlu diteliti adalah faktor internal yaitu terjadi karena sebab-sebab manajerial. Setelah dilakukan pengawasan mungkin disengaja menggunakan untuk usaha lain di luar obyek pembiayaan yang disepakati.

Cara yang dapat dilakukan untuk menangani pembiayaan macet ini apabila masih dapat diharapkan akan berjalan baik kembali, angsuran dapat dijadwal ulang. Dalam hal ini Al-Qur'an; Al Baqarah: 280 memberikan pedoman, yang artinya:

"Dan jika (orang berutang itu) dalam kesukaran maka berilah tangguh sampai dia berkelapangan. Apabila engkau menyedekahkan (sebagian atau semua hutang) maka hal itu lebih baik bagimu jika kamu mengetahui." 
Bila potensi usahanya masih baik tetapi untuk memperbaiki kondisi usahanya perlu pertambahan dana bank dapat memberikan bantuan tambahan dana, tetapi bila kondisi perusahaan sudah tidak dapat diharapkan lagi, maka lembaga dapat melakukan penghapusan piutang/pembiayaan. Al-Qur'an juga memberikan petunjuk dalam surat Al-Baqarah: 280, yang artinya:

"Apabila engkau menyedekahkan (sebagian atau semua hutang) maka hal itu lebih baik bagimu jika kamu mengetahui."

\section{d. Penyitaan Jaminan}

Penyitaan jaminan adalah tahap terakhir dari solusi pembiayaan yang bermasalah hal ini pun tidak banyak dilakukan mengingat jenis usaha yang dijalankan adalah berskala kecil.

Kalaupun dengan terpaksa harus dilakukan dengan penyitaan jaminan, maka penyitaan tetap dilakukan kepada nasabah memang nakal dan tidak mengembalikan pembiayaan namun tetap dilakukan dengan cara-cara sebagaimana yang dianjurkan menurut ajaran Islam seperti: (Muhammad, 2002: 269).

1) Simpati: sopan, menghargai, dan focus ke tujuan penyitaan

2) Empati: menyelami keadaan nasabah, bicara seakan untuk kepentingan nasabah, membangkitkan kesadaran nasabah untuk mengembalikan utangnya.

3) Menekan: tindakan ini dilakukan jika dua tindakan sebelumnya tidak diperhatikan.

Apabila cara ketiga tidak juga diacuhkan oleh nasabah, maka cara-cara yang ditempuh adalah denga terpaksa untuk:

1) Menjual barang jaminan, prosedur yang dijalankan dalam hal ini adalah jika sebelumnya telah diadakan perjanjian tertulis dalam akad.

2) Menyita barang yang senilai dengan nilai pinjaman, prosedur ini hanya dapat dilakukan jika sebelumnya telah ada perjanjian secara tertulis dalam akad. 


\section{Pemasaran Produk Pembiayaan}

Sebuah lembaga keuangan yang didirikan diharapkan mampu untuk mensosialisasikan produk yang dimiliki, dikemas guna memenuhi keinginan konsumen agar lembaga tersebut mampu bertahan ditengah maraknya kmunculan lembaga keuangan lainnya, untuk itu diperlukan serangkaian konsep pemasaran yang diharapkan bias mewujudkan tujuan lembaga sebagai financial intermediary.

Konsep pemasaran menegaskan bahwa kunci untuk mencapai tujuan organisasional yang ditetapkan adalah perusahaan tersebut harus menjadi lebih efektif dibandingkan para pesaing dalam menciptakan, menyerahkan, mengkonsumsikan nilai pelanggan, kepada pasar sasaran terpilih.(Philip Kotler, 2002: 22)

Dalam hal ini lembaga diharapkan mampu untuk melihat pasar sasaran, kebutuhan pelanggan, pemasaran terpadu dan akhirnya kemampuan menghasilkan laba.

a. Pasar Sasaran

Yang harus direncanakan dalam hal ini adalah: (Muhammad, 2001: 194-195).

- Corak persaingan (competition profile) berapa banyak volume pembiayaan yang telah dipasarkan ke masyarakat dan berapa besar market share yang berhasil dikuasai. Produk pembiayaan apa saja yang diminati.

- Corak nasabah (customer Profile) apakah kelompok pengusaha ekonomi lemah milik pemerintah atau swasta. Pemahaman atas corak nasabah ini akan sangat bermanfaat dalam sasaran pemasaran yang akan dilakukan.

b. Kebutuhan Pelanggan

Kebutuhan pelanggan terhadap produk meliputi corak produk (produk profile) yang telah dan akan dipasarkan. Berapa porsen jenis pembiayaan itu dapat disediakan dibanding dengan seluruh jenis pembiayaan perbankan dan seberapa besar daya serap pasar yang dibutuhkan nasabah. Pemahaman terhadap corak produk ini akan bermanfaat untuk menciptakan disersifikasi jenis-jenis pembiayaan 
yang dipasarkan agar lebih dapat memenuhi kebutuhan dan kepuasan para nasabahnya.

c. Pemasaran

Pemasaran terpadu merupakan ikatan kerjasama antara manajemen produk pemasarannya, pelayanannya, promosinya, semua fungsi dikoordinasikan berdasarkan keinginan pelanggan (nasabah).

d. Kemampuan Menghasilkan Laba

Kemampuan menghasilkan laba bukan menjadi tujuan utama tetapi ini penting guna mensejahterakan stakeholder dan pihak-pihak terkait tanpa mengesampingkan prinsip-prinsip syariah yang dijalankan.

Hal itu menuntut ketepatan sasaran pemasaran produk yang dikemas agar mampu memenuhi keinginan nasabah karena aktiva yang dimiliki akan bernilai kecil tanpa adanya pelanggan, itu disebabkan tidak adanya transaksi pembiayaan, dana akan mengendap dan dalam dunia perbankan ini tidak berarti baik oleh karena itu tugas utamanya adalah menarik dan mempertahankan langganan.

\section{Produk-Produk BMT Mujahidin Pontianak}

Pertama, produk pengumpulan dana. BMT Mujahidin Pontianak sebagai lembaga keuangan berbasis syari'ah memiliki tujuan memberdayakan ekonomi rakyat baik skala menengah dan kecil serta memberikan alternatif simpanan bebas dari riba. Adapun produk-produk BMT Mujahidin Pontianak sebagai berikut: 1) Simpanan Mudharabah, yaitu simpanan anggota atau nasabah BMT Mujahidin Pontianak yang dapat disetor dan ditarik setiap saat; 2) Simpanan Pendidikan, yakni simpanan untuk pembiayaan pendidikan dari tingkat TK s/d Perguruan tinggi; 3) Simpanan Qurban/Aqiqah, yaitu simpanan untuk keperluan ibadah qurban dan aqiqah; 4) Simpanan Haji, yaitu simpanan dana untuk keperluan pembiayaan ibadah haji; 5) Simpanan Berjangka, simpanan ini relatif yang paling baru muncul. Jenis simpanan ini dengan latar belakang agar pihak BMT dalam mengelola uang dari masyarakat akan lebih mudah karena 
model penarikannya demikian teratur, hanya pada saat jatuh tempo nasabah bisa menarik uangnya.

Kedua, produk pembiayaan. Ada beberapa produk pembiayaan di BMT Mujahidin Pontianak, yaitu: 1) Pembiayaan Mudharabah; 2) Pembiayaan Musyarakah; 3) Pembiayaan Murabahah; 4) Pembiayaan Ijarah; dan 5) Pembiayaan Qard al-Hasan.

\section{Sistem Penyaluran Produk Pembiayaan Pada KSU BMT Mujahidin Pontianak Tahun Buku 2009-2011.}

Bagian-bagian yang terlibat dalam system penyaluran produk pembiayaan adalah bagian pemasaran, pembiayaan dan manajer. Bagian pemasaran bertugas untuk melakukan survey mengenai kelayakan kegiatan usaha dan melengkapi semua dokumen yang diperlukan serta membuat analisa hasil survey yang berupa survey report mengenai kelayakan si nasabah. Dalam bagian pemasaran ini akan mereview hasil dari survey di lapangan tersebut apakah sudah benar atau masih ada kekurangan sebelum permohonan pembiayaan di lanjutkan.

Kemudian bagian pembiayaan yang bertugas untuk menganalisis tentang apakah nasabah yang bersangkutan memenuhi persyaratan untuk menerima pembiayaan dengan berdasarkan hasil dari survey dan kelayakan dari usaha yang dilakukan oleh nasabah, dan juga memperhatikan bad debitur dari nasabah yang mengajukan pembiayaan.

Sedangkan manajer selaku otoritas pembiayaan yang sebelumnya sudah direview oleh bagian pemasaran dan sudah dianalisa oleh bagian pembiayaan. Semua hasil survey dan dokumen yang diperlukan harus sudah lengkap ketika sampai di tangan manajer.

Adapun yang menjadi persyaratan dalam pengajuan produk pembiayaan adalah: 1) Beragama Islam; 2) Membuka rekening simpanan/ tabungan; 3) Usaha telah berjalan minimal 6 bulan; 4) Menyerahkan fotokopi KTP yang masih berlaku; 5) Mengisi formulir pembiayaan yang terdiri dari: a) surat permohonan pembiayaan; b) rincian alokasi penggunaan dana; c) memiliki surat izin baik dari suami maupun istri; d) data investigasi BMT; e)Surat pernyataan sanggup untuk memenuhi peraturan yang berlaku di BMT Mujahidin. 
Adapun dokumen dan formulir yang digunakan adalah:

1. Proposal sederhana kegiatan usaha

Dalam hal ini nasabah harus membuat suatu proposal sederhana mengenai kegiatan usahanya yang mana kegiatan usaha telah berjalan minimal 6 bulan dengan tempat usaha menetap.

2. Dokumen check list

Dokumen check list sebagai recheck terhadap kelengkapan persyaratan pembiayaan nasabah dimana yang melakukan pengecekan ini adalah bagian pemasaran.

3. Survey report

Formulir ini digunakan sebagai hasil usaha atas survey yang dilakukan terhadap nasabah yang akan melakukan pembiayaan kepada BMT Mujahidin. Jika hasil survey tersebut layak, maka akan dilanjutkan pemberian formulir permohonan pembiayaan untuk nasabah.

4. Formulir permohonan pembiayaan nasabah

Formulir ini digunakan oleh nasabah dalam rangka pengujian aplikasi permohonan pembiayaan murabahah, BBA maupun mudlarabah kepada pihak BMT Mujahidin yang ditandatangani oleh bagian pemasaran dan nasabah.

5. Proposal investasi

Formulir ini dilakukan oleh bagian pemasaran sebanyak 4 lembar. Proposal investasi yang dibuat tersebut harus mendapatkan persetujuan/ ditandatangani oleh bagian pemasaran dan manajer.

6. BRP (Bukti Realisasi Pembiayaan)

BRP ini dikeluarkan oleh manajer sebagai bukti persetujuan pembiayaan dan jumlah pembiayaan yang disetujui sebelumnya.

7. SRP (Surat Realisasi Pembiayaan)

SRP dikeluarkan oleh bagian kasir setelah adany BRP bagian keuangan dan BRP dari nasabah untuk dilaksanakan pencairan dana pembiayaan nasabah. 


\section{Perjanjian Pembiayaan Nasabah}

Merupakan surat perjanjian antara nasabah dan pihak BMT Mujahidin mengenai pembiayaan yang berisikan persyaratan dan ketentuan tentang pembiayaan kepada BMT Mujahidin yang ditandatangani nasabah diatas materai dan disertai dengan stempel BMT Mujahidin.

Dalam pengelolaan pembiayaan yang telah berhasil disalurkan BMT Mujahidin telah menerapkan beberapa kebijaksanaan dalam pengelolaan yaitu:

1. Dalam pemberian pinjaman terdapat perbedaan anggota yang satu dengan anggota yang lainnya, hal ini dikarenakan usaha yang dikelola oleh anggota pembiayaan adalah usaha yang bersifat musiman.

2. Dalam sistem pengembalian pinjman pihak BMT selain menetapkan jangka waktu pengembalian juga memberikan batas toleransi pengembalian bagi anggota jika belum bias melunasi pada saat jatuh tempo pengembalian, hal ini dikarenakan bidang yang dikelola oleh anggota berbeda-beda.

3. Untuk mengurangi pembiayaan macet, maka anggota diwajibkan untuk menabung dari sebagian hasil usahanya pada saat melakukan pencicilan pembayaran. Hal ini sekaligus dimaksudkan agar kemudian hari mereka dalam memenuhi kebutuhan permodalan dengan tabungan itu.

4. Pengelolaan BMT berusaha untuk lebih memfokuskan diri pada pembiayaan yang ditujukan untuk usaha kecil, nantinya berpengaruh terhadap restasi mendapatkan laba yang pada akhirnya berpengaruh terhadap laba usaha bagi BMT Mujahidin.

Bagan alur sistem pembiayaan BMT Mujahidin menunjukkan bagian yang terkait dan dokumen yang digunakan serta proses pelaksanaan kegiatan tersebut.

Adapun sistem pemberian pembiayaan dapat diuraikan sebagai berikut: 
1. Nasabah mengajukan permohonan dengan membuat proposal sederhana mengenai kegiatan usahanya.

2. Proposal kegiatan usaha nasabahnya tersebut akan diserahkan ke bagian pemasaran untuk diproses mengenai kelayakan atas persyaratan. Dalam hal ini bagian pemasaran akan mencocokannya dengan buku yang berisi tentang persyaratan dalam memperoleh pembiayaan di BMT Mujahidin Kota Pontianak.

3. Sesudah dilakukan pencocokan/penyesuaian atas proposal pembiayaan, maka akan diperoleh suatu proposal pembiayaan yang sudah sesuai dengan persyaratan. Kemudian diadakan survey dari pihak BMT dalam hal ini dilakukan oleh bagian pemasaran untuk mengetahui kelayakan usaha dan segala sesuatunya berdasarkan proposal usaha tersebut.

4. Apabila berdasarkan hasil survey usahanya, maka si nasabah wajib untuk mengisi formulir permohonan pembiayaan yang disediakan oleh BMT Mujahidin.

5. Setelah formulir permohonan pembiayaan diisi dan dilengkapi oleh nasabah, kemudian formulir tersebut diserahkan kembali ke bagian pemasaran untuk dibuat proposal investasi sebanyak 1 lembar.

6. Manajer menerima 1 lembar proposal investasi nasabah dari bagian pemasaran untuk disahkan/diotorisasi. Setelah dilakukan penandatanganan oleh manajer, maka manajer akan mengeluarkan 3 lembar yang nantinya diserahkan kepada:

- Lembar 1 untuk nasabah

- Lembar 2 untuk bagian keuangan

- Lembar 3 untuk arsip

7. Bagian keuangan menerima Bukti Realisasi Pembiayaan yang sudah diotorisasi oleh manajer kemudian bagian keuangan akan mengeluarkan formulir pencairan dana yang selanjutnya akan diproses terlebih dahulu guna dilakukan realisasi pembiayaan. Setelah proses realisasi pembiayaan, dibuatlah bukti pengeluaran kas yang dibuat sebanyak 2 lembar. 
- Lembar 1 untuk kasir

- Lembar 2 untuk arsip

8. Dari arsip lembar 2 bukti pengeluaran kas, bagian keuangan akan membuat laporan buku harian yang nantinya akan direkap dan diserahkan ke bagian manajer. Kemudian manajer akan melakukan pemeriksaan atas laporan harian tersebut.

9. Kasir akan menerima bukti pengeluaran kas dari bagian keuangan dan BRK dari nasabah. Selanjutnya akan mengeluarkan Surat Realisasi Pembiayaan. Dan kasir menyiapkan pembayaran tunai sesuai dengan yang disetujui oleh manajer BMT.

Dari realisasi pembiayaan yang dilakukan ada beberapa pertimbangan yang melandasi pembiayaan antara lain analisa keuangan yang meliputi kinerjanya antara lain kemampuan melemparkan pembiayaan, kecukupan modalnya juga, kemampuan melayani dana-dana yang harus likuid.

Pembiayaan terjadi bukan hanya didukung oleh permodalan lembaga tersebut tetapi didukung oleh pihak-pihak ketiga, perencanaan yang benar-benar matang sangat diperlukan dalam hal ini dikarenakan, atas dana mengendap tersebut lembaga harus memperhatikan kesejahteraan para stakeholder dalam bentuk pembagian hasil usaha atas dana yang diinvestasikan. Melalui pembiayaan ini juga peran lembaga keuangan sebagai financial intermediary semakin Nampak.

\section{Pengawasan Terhadap Pembiayaan Pada KSU BMT Mujahidin Tahun Buku 2009-2011}

Setelah adanya realisasi pembiayaan bukan berarti tugas BMT Mujahidin selesai begitu saja. Salah satu faktor penting yang dilakukan adalah dengan mengadakan fungsi pengawasan. Pelaksanaan pengawasan pembiayaan pada KSU BMT Mujahidin Pontianak secara kontinu dilakukan guna menjamin pembiayaan serta menghindari pembiayaan bermasalah.

Kegiatan pengawasan yang dilakukan oleh BMT Mujahidin dapat dikelompokkan: 


\section{Pengawasan Aktif atau pengawasan Langsung}

Yaitu pengawasan oleh BMT yang dilakukan dengan mengadakan pemeriksaan langsung ke tempat usaha nasabah. Pemeriksaan ini sangat penting karena dengan jalan inilah BMT dapat mengetahui keadaan yang sebenarnya dari usaha nasabah yang dibiayai dengan dana pembiayaan. Pengawasan ini dilakukan oleh AO (Bagian pemasaran). Bagi nasabah yang sistem pembayaran pembiayaannya cicilan setiap hari, maka pihak BMT dapat mengawasi perkembangan nasabahnya atau mitranya. Karena setiap hari pihak BMT mendatangi mitranya tersebut. Dengan demikian secara langsung pihak BMT dapat membimbing sekaligus mengawasi perkembangan usaha mitra.

Pengawasan ini disebut sebagai Inspeksi on the spot, artinya pengawasan ini sangat penting dilakukan karena dapat membantu BMT dalam mengambil langkah-langkah prefentif yang dilakukan. Oleh karena itu inspeksi on the spot perlu dilakukan tidak hanya bersifat eksidentil tetapi juga harus dilakukan secara rutin. Hal ini ditujukan bagi semua nasabah tidak terkecuali bagi nasabah yang mengalami permasalahan dan pihak BMT juga harus melakukan penyelamatan terhadap pembiayaan tersebut. Kunjungan kepada nasabah yang dilakukan secara rutin setiap hari atau setiap bulan hingga bila terjadi permasalahan, maka pihak BMT Mujahidin dapat segera membantu mencarikan jalan keluar bagi nasabah.

Dengan kata lain, dari kunjungan ke tempat nasabah tersebut dapat mengetahui hal-hal apakah yang perlu mendapat bimbingan atau pembinaan. Pihak BMT juga dapat melakukan kegiatan telephone call kepada nasabah bilaman nasabah pembiayaan tersebut mengalami tunggakan dalam pembayaran cicilan. Selain itu telephon call juga dilakukan untuk menciptakan hubungan yang baik antara pihak BMT dan nasabahnya selaku mitra BMT.

2. Pengawasan Administrasi

Yaitu pengawasan dimana BMT dalam memberikan pembiayaan kepada nasabah harus mengawasi secara detail proses pembiayaan mulai pengajuan sampai dengan pencairan sehingga jika ada 
pihak yang melanggar kewenangannya dapat segera diketahui dan dapat ditindak.

Pengawasan yang dilakukan yaitu: mulai pada saat proses pengajuan dengan cara memeriksa kelengkapan persyaratan hingga sampai pada tahap pencairan. Dan juga petugas administrasi ini harus memisahkan berkas-berkas tersendiri antara nasabah, sehingga mudah dalam melakukan review. Pengawasan ini dilakukan oleh CS (Administrasi Pembiayaan).

Pengawasan ini merupakan salah satu objek pengawasan pembiayaan untuk mengumpulkan kelengkapan surat-surat seperti KTP, KK dan surat-surat kelengkapan lainnya seperti pada saat pengajuan pembiayaan.

3. Pembinaan Terhadap Nasabah

Pelaksanaan pembiayaan harus disertai dengan pembinaan terhadap nasabah. Tanpa adanya pembinaan maka pengawasan yang dilakukan tidak ada artinya. Pihak BMT Mujahidin tidak hanya semata-mata melakukan pemantauan terhadap pembayaran cicilan tetapi juga membantu memberikan masukan guna menyelesikan permasalahan yang dihadapi nasabah sedari dini mungkin.

Langkah-langkah yang dilakukan pihak BMT dalam mengatasi permasalahan nasabah, antara lain:

a. Mengadakan penelitian apakah pembiayaan yang diberikan oleh BMT Mujahidin telah dipergunakan sesuai dengan syarat-syarat dan tujuan yang telah ditetapkan sebelumnya. Bilamana terjadi penyimpangan, sampai seberapa jauh penyimpangan tersebut dapat ditolerir dengan memperhatikan risiko yang mungkin terjadi.

b. Meneliti apakah asumsi-asumsi yang dijadikan dasar pertimbangan pemberian pembiayaan sesuai dengan kenyataan di lapangan.

c. Membantu mencari jalan keluar dalam hal nasabah menghadapi suatu masalah. 
d. Meneliti sampai seberapa jauh kemungkinan pengembangan pembiayaan di sector usaha nasabah.

\section{Penutup}

Berdasarkan hasil pembahasan yang dilakukan terhadap data-data yang berhasil dikumpulkan di lapangan dan dipaparkan sebelumnya maka dapat dikemukakan beberapa kesimpulan, diantaranya bahwa KSU BMT Mujahidin dalam menyalurkan pembiayaan sama dengan lembaga keuangan syariah lainnya, yakni pembiayaan yang dijalankan memiliki serangkaian prosedur yang disusun secara sistematis dari bagian yang terlibat yaitu pemasaran, pembiayaan dan manajer telah cukup efektif. Pengajuan pembiayaan dimulai dari mengisi form permohonan, kemudian melengkapi persyaratan administrasi seperti identitas diri, KK dan photo dan diserahkan ke marketing. Pihak marketing menerima berkas permohonan, melakukan wawancara, menganalisa, survey ke tempat usaha, membuat laporan hasil survey, dan jika layak maka dilanjutkan dengan membuat proposal investasi dan diserahkan ke MO. Manajer menerima permohonan, menganalisa jika disetujui maka akan di tandatangani oleh manajer.

Adapun pengawasan terhadap produk dilakukan dengan tiga pengelompokan, pertama, dengan melakukan pengawasan aktif atau langsung, yakni pengawasan oleh BMT yang dilakukan dengan mengadakan pemeriksaan langsung ke tempat usaha nasabah. Pemeriksaan ini sangat penting karena dengan jalan inilah BMT dapat mengetahui keadaan yang sebenarnya dari usaha nasabah yang dibiayai dengan dana pembiayaan. Pengawasan ini dilakukan oleh AO (Bagian pemasaran). Kedua, pengawasan administrasi, yakni pengawasan yang dilakukan mulai pada saat proses pengajuan dengan cara memeriksa kelengkapan persyaratan hingga sampai pada tahap pencairan. Ketiga, membantu nasabah dalam mengidentifikasi permasalahan yang akan muncul sedini mungkin. Jika terjadi pembiayaan macet maka pihak BMT Mujahidin tidak lepas tangan, pihak BMT ikut andil dalam mencarikan solusi bagi nasabah. 


\section{DAFTAR PUSTAKA}

Antonio, Syafi'i. 2001. Bank Syari'ah dari Teori ke Praktek. cet. 1. Jakarta: Gema Insani Press.

Arifin. Zainul. 2001. Memahami Bank Islam. Jakarta: Alfabeth. , 2004. Manajemen Dana Bank Syariah. Jakarta: Alfabeth.

Dendawijaya, Lukman. 2003. Manajemen Perbankan. Jakarta: Rajawali Pers Departemen Agama. Al Qur'anul Karim.

IBI Tim Pengembangan Perbankan Syari'ah. 2003. Konsep Bank dan Implementasi Bank Syari'ah. Jakarta: Djambatan.

Karim, Adiwarman. Bank Islam. 2004. Jakarta: Grafindo

Kotler, Philip. 2002. Manajemen Pemasaran. Jakarta: IKAPI. Edisi Millenium 1.

Muhammad. 2000. Lembaga-lembaga Keuangan Umat Komtemporer, cet. 1. Yogyakarta: UII Press.

. 2001. Manajemen Bank Syari'ah. Yogyakarta: UPP AMP YKPN. . 2002. Manajemen Bank Syari'ah. Edisi revisi kedua. Yogyakarta: UPP AMP YKPN.

2005 Manajemen Pembiayaan Bank Syariah, Yogyakarta: UPP AMP YKPN.

Rodoni, Ahmad dan Abdul Hamid. 2008. Lembaga Keuangan Syariah. Jakarta: Zikrul Hakim.

Sudarsono, Heri. 2003. Konsep Ekonomi Islam: Suatu Pengantar. Yogyakarta: Ekonisia FE UII.

. 2004. Bank dan Lembaga Keuangan Syari'ah. Yogyakarta: Ekonosia FE UII.

Syahdeni, Sutan Remi. 2005. Perbankan Islam. Jakarta: Grafiti.

Veitzal. 2012. Islamic Banking and Finance. Yogyakarta: BPFE.

Zuhayli, Wahbah Az. 1989. Al-Figh Al-Islam Wa Adillatuhu. Kairo: Dar AlFikr. 